\title{
First case of periprosthetic joint infection due to Clostridioides difficile in China
}

\author{
Yang Song ${ }^{1}$, Hong Yi Shao ${ }^{1}$, Xiang Cheng $^{2}$ and Yu Guo ${ }^{2^{*}}$ (D)
}

\begin{abstract}
Background: Clostridioides difficile usually causes intestinal infections. However, a 75-year-old lady had a periprosthetic joint infection due to this microorganism. We report a $C$. difficile infection of a prosthetic hip joint. Such an infection is rarely reported around the world.

Case presentation: The elder female patient presented with a 2-year history of right hip pain with movement restriction. Her right leg was shorter than another. The skin around the right hip joint was red and swollen without sinus. Her lab test result showed elevator ESR and CRP. Her X-ray film showed a massive bone defect. The patient had a total hip arthroplasty 16 years ago and had a revision 5 years ago. During this hospitalization, her cultures of the synovial fluid and tissue repeatedly grew $C$. difficile. She improved following two-stage revision surgery and antibiotic treatment. The patient has no recurrence of infection after a one-year follow-up.
\end{abstract}

Conclusion: A rapid and accurate sample collection is significant for culture results, making an outstanding contribution to the successful treatment.

Keywords: Periprosthetic joint infection, Clostridioides difficile, Antibiotic treatment, Case report

\section{Background}

Total hip arthroplasty (THA) is a very effective surgery for the treatment of late-stage osteoarthritis. However, periprosthetic joint infection (PJI) is a potentially catastrophic complication that affects nearly 1 to $3 \%$ of patients who have undergone THA $[1,2]$. Gram-positive cocci constitute more than two-thirds of the pathogenic organisms in PJI; other cases involve Gram-negative bacteria, fungi, or other organisms [3]. There are 35\% [4, 5] of cases of prosthetic joint infection without detection of the infectious agent. Clostridioides difficile is a spore-forming, toxinproducing Gram-positive anaerobe, which usually causes intestinal infections, has rarely been reported in cases of PJI. When anaerobic culture is applied, $C$.

\footnotetext{
* Correspondence: muyuyuyu@yeah.net

${ }^{2}$ Department of Microbiology and Molecule Laboratory, Jishuitan Hospital and Fourth Medical College of Peking University, 31 East Street, Xinjiekou, Xicheng District, Beijing 100035, CN, China

Full list of author information is available at the end of the article
}

difficile is well culturable. Only five cases [6-10] of PJI involving $C$. difficile have been reported in the literature to date. Among them, two were ultimately resolved by amputation. To the best of our knowledge, no such cases have been reported in China. We herein report the first known case of PJI caused by $C$. difficile after THA in China and describe the isolation technique and treatment of this microorganism.

\section{Case presentation}

A 75-year-old woman presented with a 2-year history of right hip pain with restriction of movement. She had undergone right hip arthroplasty because of a traumatic fracture 16 years previously; 5 years ago, she underwent a revision for joint pain and limit movement. She had no comorbidities. Her hip pain had recurred 2 years ago, and she was treated with second-generation cephalosporin for her symptoms (night pain, elevated temperature, swollen area of the hip), and her erythrocyte sedimentation rate (ESR) was $60 \mathrm{~mm} / \mathrm{h}$ (normal

(c) The Author(s). 2021 Open Access This article is licensed under a Creative Commons Attribution 4.0 International License, which permits use, sharing, adaptation, distribution and reproduction in any medium or format, as long as you give appropriate credit to the original author(s) and the source, provide a link to the Creative Commons licence, and indicate if changes were made. The images or other third party material in this article are included in the article's Creative Commons licence, unless indicated otherwise in a credit line to the material. If material is not included in the article's Creative Commons licence and your intended use is not permitted by statutory regulation or exceeds the permitted use, you will need to obtain permission directly from the copyright holder. To view a copy of this licence, visit http://creativecommons.org/licenses/by/4.0/ The Creative Commons Public Domain Dedication waiver (http://creativecommons.org/publicdomain/zero/1.0/) applies to the data made available in this article, unless otherwise stated in a credit line to the data. 
range $0 \sim 10 \mathrm{~mm} / \mathrm{h}$ ), and her C-reactive protein (CRP) concentration was $304 \mathrm{mg} / \mathrm{L}$ (normal range $0 \sim 10 \mathrm{mg} /$ L). The lab test result came to normal, but the pain still existed after the antibiotic treatment. Her pain and disability had increased during the most recent 2 months.

The patient arrived at our hospital in a wheelchair. Physical examination showed that her right lower extremity was shortened and that her hip exhibited flexion contracture; the skin around the hip joint was red, swollen without sinus. Her preoperative ESR was $43 \mathrm{~mm} / \mathrm{h}$, and her CRP was $20.4 \mathrm{mg} / \mathrm{L}$. Before the first stage, the $\mathrm{X}$-ray film showed a massive bone defect of the proximal femur, making the leg shortened (Fig. 1a).

Aspiration of the patient's hip joint produced almost $30 \mathrm{~mL}$ of synovial fluid. The synovial fluid examination revealed a white cell count (WBC) of $7548 / \mathrm{mm} 3$ with a polymorphonuclear neutrophil (PMN) percentage of $77 \%$. We inoculated samples of the synovial fluid into four blood culture vials (two aerobic and two anaerobic vials) and cultured them using an instrumented blood culture system (BACTECTM FX 100, Becton, Dickinson and Company, New Jersey, US). The two anaerobic culture vials exhibited growth at 44 and $62 \mathrm{~h}$ after inoculation, respectively; we then performed a Gram stain of the samples and found Gram-positive bacilli under microscopy (Fig. 2). Gray-white wet colonies of medium size, round shape, and irregular edges were observed in the anaerobic medium after $24 \mathrm{~h}$ of incubation (Fig. 3). The organism was identified as $C$. difficile by matrixassisted laser desorption/ionization time-of-flight mass spectrometry (MALDI-TOF MS, Bruker Corporation, Nehren, Germany). Identification was confirmed by $16 \mathrm{~S}$ rRNA sequencing. Polymerase chain reaction tested (Tsingke company, Beijing, China) positively for the $t c d A$ and $t c d B$ genes of $C$. difficile. Antimicrobial testing showed that the bacterium was sensitive to

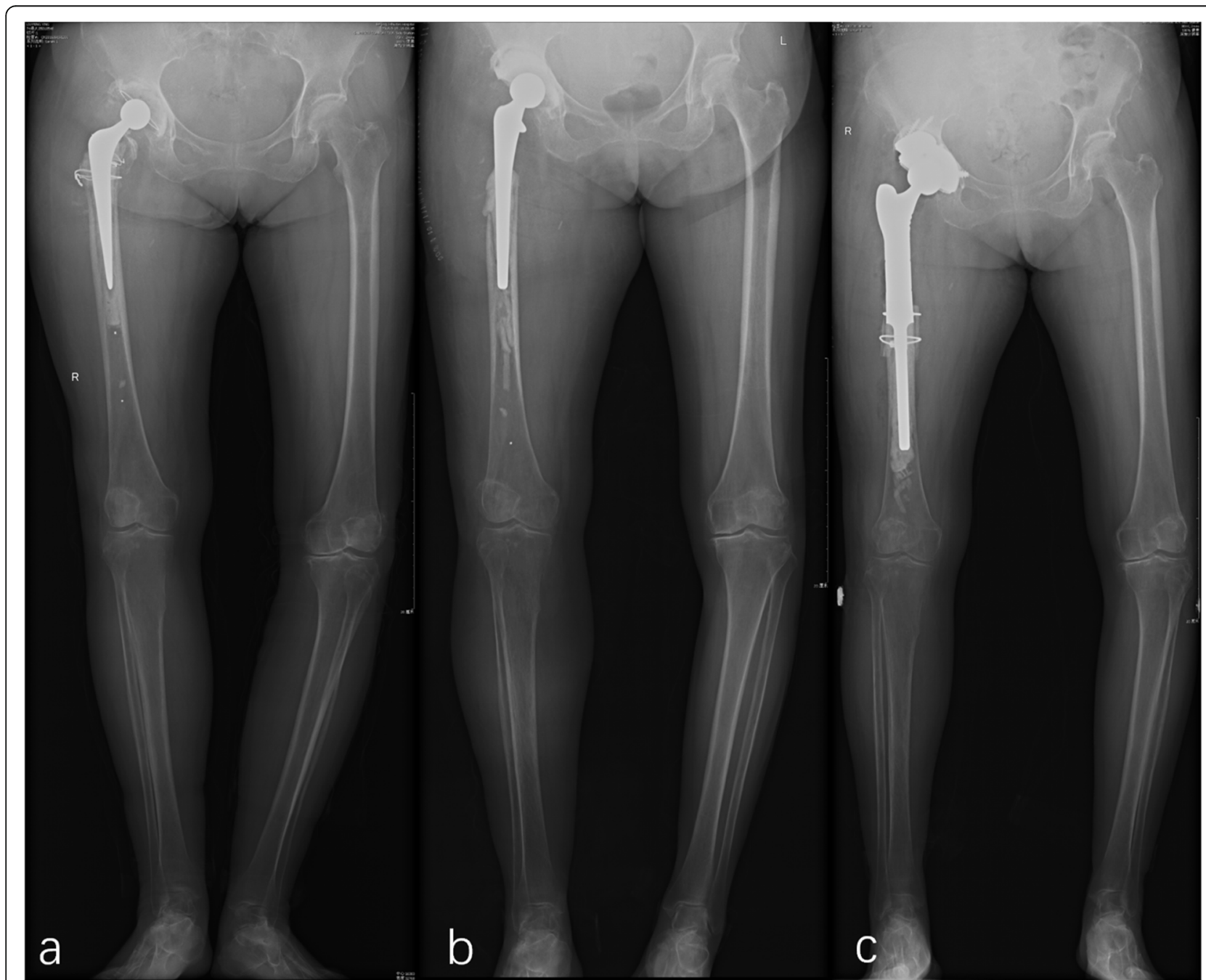

Fig. 1 X-ray films of this two-stage treatment. $\mathbf{a}$ : $\mathrm{X}$-ray film of the patient before the first stage operation; $\mathbf{b}$ : $\mathbf{X}$-ray film of the patient after the first stage operation; $\mathbf{c}$ : $\mathbf{X}$-ray film of the patient before the second stage operation 


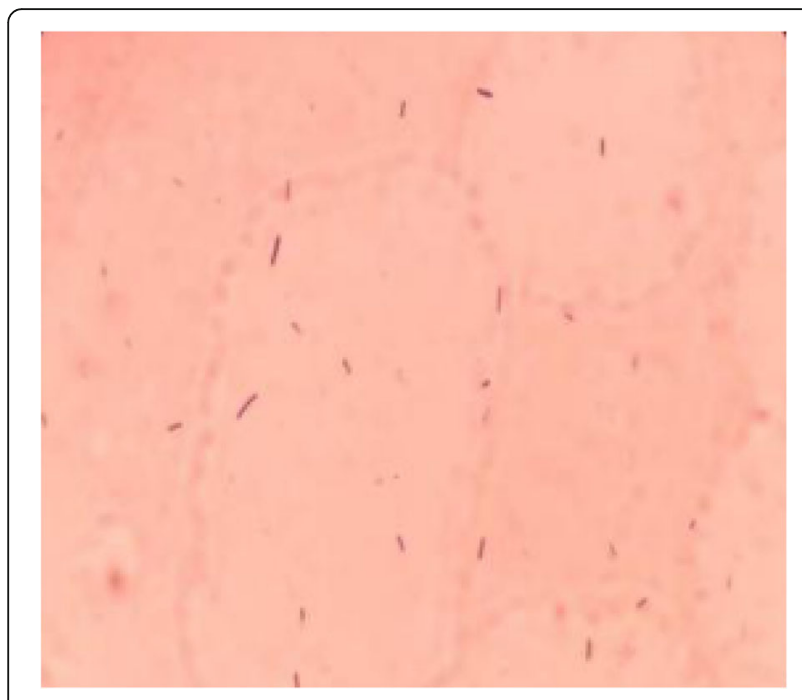

Fig. 2 Gram-stain, microscopic morphology of Clostridium difficile (1000x)

metronidazole and vancomycin (Etest, BIOMERIEUX, Paris, France).

We performed a two-stage revision for treatment of this patient. In the first stage, we removed the prosthesis and performed thorough debridement; this was followed by the placement of a cement spacer mixed with vancomycin (Fig. 1b). We mixed $4 \mathrm{~g}$ vancomycin in $36 \mathrm{~g}$ cement (PALACOS ${ }^{\circ}$, Heraeus Medical GmbH, Wehrheim, Germany). Intraoperative cultures of the synovial fluid and tissue repeatedly grew $C$. difficile. The antimicrobial susceptibility results were unchanged from the previous cultures. According to the results of

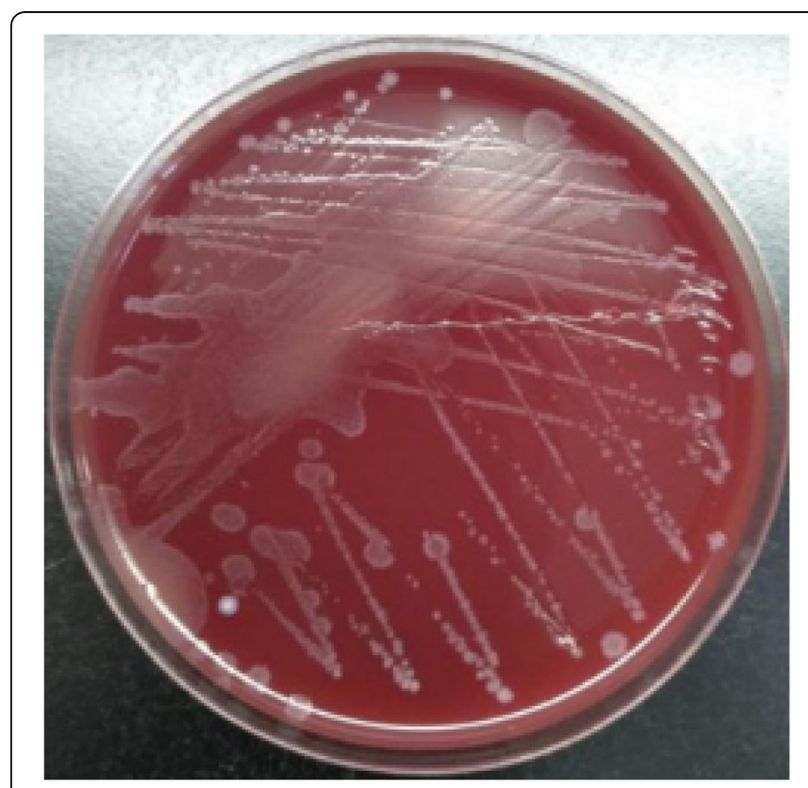

Fig. 3 Colony morphology of Clostridium difficile on anaerobic blood agar (24-h culture) antimicrobial testing, metronidazole was selected for treatment. The patient was treated with intravenous metronidazole for 2 weeks postoperatively and oral metronidazole ( $400 \mathrm{mg}$ three times a day) for another 4 weeks. She then underwent the second stage of hip reconstruction after confirming that her laboratory parameters were normal (CRP: $2.65 \mathrm{mg} / \mathrm{L}$; ESR: $26 \mathrm{~mm} / \mathrm{h}$ ). We used a tumor prosthesis to reconstruct her femur bone defect. And we used augment to econstruct the acetabular (Fig. 1c). We obtained intraoperative samples again to ensure that the infection was under control. We checked an intraoperative cell count (WBC: $247 / \mathrm{mm}^{3}$; PMN percentage: 7\%). Cultures of all samples showed no growth, and the patient underwent another round of antibiotic treatment (2 weeks of intravenous metronidazole and another 4 weeks of oral metronidazole, as before). She returned for regular follow-ups. At her latest follow-up, 1 year after the diagnosis of PJI due to $C$. difficile, her right hip was pain-free, and the incision had healed without clinical signs of infection.

\section{Discussion and conclusions}

Clostridioides difficile (previously termed Clostridium difficile) is a pathogen that causes antibiotic-associated diarrhea and pseudomembranous colitis with clinical manifestations of diarrhea, abdominal pain [11]. Significant risk factors for developing $C$. difficile infection (CDI) include antibiotic use, older age, poor host immune function, proton pump inhibitor use, previous $\mathrm{CDI}$, and diabetes [12]. However, few extraintestinal CDI cases have been reported, especially bone and joint infections such as septic arthritis, osteomyelitis, and PJI. To date, only five patients have been reported to have PJI due to $C$. difficile; among them, two ultimately required amputation [6-10]. One of these cases was reported in 1995; a 16-year-old boy developed CDI after total knee arthroplasty in France and underwent leg amputation 1 year later. The other case involved a 61-yearold woman in the United States; a strain of $C$. difficile was isolated from tissue and fluid aspirated from her knee. The patient underwent an above-knee amputation 3 months later. In such cases, the reason for treatment failure is speculated to be associated with bacterial virulence and high antibiotic resistance. We have summarized all previously reported cases in Table 1 .

Our patient had undergone long-term administration of various antibiotics, which substantially increased her risk of CDI. Because we isolated the same strain of $C$. difficile from both the preoperative synovial fluid and intraoperative tissue culture, we were sure that the $C$. difficile was the pathogenic organism of the PJI and was not a contaminant. However, the patient developed no diarrhea or other gastrointestinal symptoms during her hospitalization, and we did not examine her feces. 
Table 1 Summary of Cases

\begin{tabular}{|c|c|c|c|c|c|c|}
\hline & Case 1 [6] & Case 2 [7] & Case 3 [8] & Case 4 [9] & Case 5 [10] & This case \\
\hline $\begin{array}{l}\text { Region/ } \\
\text { Time }\end{array}$ & France/1995 & Australia/1999 & America/2013 & America/2013 & Belgium/2014 & China/2019 \\
\hline $\begin{array}{l}\text { Patient's } \\
\text { age and } \\
\text { sex }\end{array}$ & 16-year-old man & 83-year-old woman & $\begin{array}{l}\text { 61-year-old } \\
\text { woman }\end{array}$ & 47-year-old woman & $\begin{array}{l}\text { 61-year-old } \\
\text { man }\end{array}$ & 75-year-old woman \\
\hline $\begin{array}{l}\text { Site of } \\
\text { infection }\end{array}$ & knee & hip & knee & shoulder & hip & hip \\
\hline $\begin{array}{l}\text { Type of } \\
\text { infection }\end{array}$ & late (16 months later) & $\begin{array}{l}\text { delayed (12 months } \\
\text { later) }\end{array}$ & $\begin{array}{l}\text { early ( } 3 \text { months } \\
\text { later) }\end{array}$ & early (3 months later) & $\begin{array}{l}\text { early ( } 1 \text { week } \\
\text { later) }\end{array}$ & late (24 months later) \\
\hline $\begin{array}{l}\text { Surgical } \\
\text { treatment }\end{array}$ & $\begin{array}{l}\text { arthrotomy with drainage, } \\
\text { removal of implant }\end{array}$ & $\begin{array}{l}\text { Revision of the hip } \\
\text { and removal of } \\
\text { implant }\end{array}$ & $\begin{array}{l}\text { Removal of } \\
\text { implant }\end{array}$ & $\begin{array}{l}\text { Debridement with } \\
\text { removal of the } \\
\text { hardware }\end{array}$ & $\begin{array}{l}\text { Debridement, } \\
\text { retention }\end{array}$ & $\begin{array}{l}\text { Debridement, two- } \\
\text { stage exchange } \\
\text { arthroplasty }\end{array}$ \\
\hline $\begin{array}{l}\text { Antibiotic } \\
\text { treatment }\end{array}$ & $\begin{array}{l}\text { Amoxicillin/ornidazole/ } \\
\text { rigampicin/lincomycin/ } \\
\text { penicillin G }\end{array}$ & Metronidazole & $\begin{array}{l}\text { Piperacillin- } \\
\text { tazobactam/ } \\
\text { Metronidazole }\end{array}$ & $\begin{array}{l}\text { Vancomycin/ } \\
\text { Metronidazole }\end{array}$ & $\begin{array}{l}\text { Vancomycin/ } \\
\text { Metronidazole }\end{array}$ & $\begin{array}{l}\text { Vancomycin/ } \\
\text { Metronidazole }\end{array}$ \\
\hline Outcome & Amputation & Successful & Amputation & Unknown & Successful & Successful \\
\hline
\end{tabular}

Because there was no directly anatomical way between the abdominal and the hip joint, we speculate that the $C$. difficile had reached the hip joint by hematogenous spread as previously described [13].

We considered that the culture result would be the critical factor in a successful outcome during our patient's treatment. Previous reports have shown that the most critical risk factor for misdiagnosis of CDI is the process of sample collection [14]. If this collection process is not done quickly and correctly, the test results may be strongly influenced. In particular, because $C$. difficile is a Gram-positive anaerobe, it should be kept in an anaerobic environment. Previous research has shown that testing such samples should be completed in $2 \mathrm{~h}$ to increase the positivity rate [15]. Blood culture vials are commonly used to store synovial fluid samples in the hospital [16]; however, storage duration before testing in the clinical laboratory may be too long. There was a special recommendation [17] for treating CDI in intestinal but the joint. Metronidazole and vancomycin are recommended for the treatment of colonic CDI by the Infectious Diseases Society of America [18]. Our patient underwent two-stage exchange arthroplasty combined with a long antibiotic therapy course and showed a good outcome after 1 year of follow-up.

In conclusion, rapid sample collection is critically important in the clinical setting. An appropriate surgical technique and metronidazole anti-infection therapy significantly contributed to the successful result in this case.

\section{Abbreviations}

THA: Total hip arthroplasty; PJl: Periprosthetic joint infection; C. difficile: Clostridioides difficile; CDI: Clostridioides difficile infection; CRP: Creactive protein; ESR: Erythrocyte sedimentation rate; WBC: White cell count; PMN: Polymorphonuclear neutrophil

\section{Acknowledgments}

Not applicable.

\section{Authors' contributions}

YS analyzed and interpreted the patient data regarding clinical infectious diseases presentation and provided the interpretation of follow-up in the patient. HS provided interpretation regarding surgical and pharmacological treatment for the patient. XC isolated and identified the strain of C. difficile in the patient. YG characterized and interpreted the virulence genes for this organism. All authors have read and approved the final manuscript.

Funding

There was no funding source for this report.

\section{Availability of data and materials}

Data sharing is not applicable to this article as no datasets were generated or analyzed as a part of this case report.

\section{Declarations}

Ethics approval and consent to participate

The patient in this case report and her families were informed that the information from the case, including her photographs, would be submitted for publication, and they gave their consent.

\section{Consent for publication}

Written informed consent was obtained from the patient for publication of this case report and any accompanying images. A copy of the written consent is available for review by the Editor of this journal.

This manuscript has not been published in whole or in part, nor is it being considered for publication elsewhere. All authors have reviewed the final version of the manuscript and approved it for publication.

\section{Competing interests}

The authors declare that there are no financial or other relationships that might lead to a conflict of interest in the present article.

\section{Author details}

'Department of Orthopaedic, Jishuitan Hospital and Fourth Medical College of Peking University, Beijing, China. ${ }^{2}$ Department of Microbiology and Molecule Laboratory, Jishuitan Hospital and Fourth Medical College of Peking University, 31 East Street, Xinjiekou, Xicheng District, Beijing 100035, $\mathrm{CN}$, China. 
Received: 1 October 2020 Accepted: 12 May 2021

Published online: 21 May 2021

\section{References}

1. Kramer TS, Gastmeier P, Remschmidt C. Prosthetic joint infections. Lancet Infect Dis. 2018;18(12):1308. https://doi.org/10.1016/S1473-3099(18)30670-4

2. Fehring TK, Fehring KA, Hewlett A, Higuera CA, Otero JE, Tande A. What's new in musculoskeletal infection. J Bone Joint Surg Am. 2019;101(14):123744. https://doi.org/10.2106/JBJS.19.00403.

3. Tande AJ, Gomez-Urena EO, Berbari EF, Osmon DR. Management of Prosthetic Joint Infection. Infect Dis Clin N Am. 2017;31(2):237-52. https:// doi.org/10.1016/j.idc.2017.01.009.

4. Atkins BL, Athanasou N, Deeks JJ, Crook DWM, Simpson H, Peto TEA, et al. Prospective evaluation of criteria for microbiological diagnosis of prostheticjoint infection at revision arthroplasty. J Clin Microbiol. 1998;36(10):2932-9. https://doi.org/10.1128/JCM.36.10.2932-2939.1998.

5. Bejon P, Berendt A, Atkins BL, Green N, Parry H, Masters S, et al. Two-stage revision for prosthetic joint infection: predictors of outcome and the role of reimplantation microbiology. J Antimicrob Chemother. 2010;65(3):569-75. https://doi.org/10.1093/jac/dkp469.

6. Pron B, Merckx J, Touzet P, Ferroni A, Poyart C, Berche P, et al. Chronic septic arthritis and osteomyelitis in a prosthetic knee joint due to Clostridium difficile. Eur J Clin Microbiol Infect Dis. 1995;14(7):599-601. https://doi.org/10.1007/BF01690732.

7. McCarthy J, Stingemore N. Clostridium difficile infection of a prosthetic joint presenting 12 months after antibiotic-associated diarrhea. J Inf Secur. 1999; 39(1):94-6.

8. Curtis L, Lipp MJ. Clostridium difficile infection of a prosthetic knee joint requiring amputation. Surg Infect. 2013;14(1):163-4. https://doi.org/10.1089/ sur.2012.098.

9. Ranganath S, Midturi JK. Unusual case of prosthetic shoulder joint infection due to Clostridium difficile. Am J Med Sci. 2013;346(5):422-3. https://doi. org/10.1097/MAJ.0b013e3182987d05.

10. Brassinne L, Rodriguez-Villalobos $H$, Jonckheere $S$, Dubuc JE, Yombi JC. Early infection of hip joint prosthesis by Clostridium difficile in an HIV-1 infected patient. Anaerobe. 2014;27:96-9. https://doi.org/10.1016/j.ana erobe.2014.03.007.

11. Abt MC, McKenney PT, Pamer EG. Clostridium difficile colitis: pathogenesis and host defense. Nat Rev Microbiol. 2016;14(10):609-20. https://doi.org/1 0.1038/nrmicro.2016.108.

12. Brown K, Valenta K, Fisman D, Simor A, Daneman N. Hospital ward antibiotic prescribing and the risks of Clostridium difficile infection. JAMA Intern Med. 2015;175(4):626-33. https://doi.org/10.1001/jamainternmed.2 014.8273 .

13. Brook I. Microbiology and management of joint and bone infections due to anaerobic bacteria. J Orthop Sci. 2008;13(2):160-9. https://doi.org/10.1007/ s00776-007-1207-1.

14. Bouza E, Alcalá L, Reigadas E. Optimizing the diagnostic testing of Clostridium difficile infection. Expert Rev Anti-Infect Ther. 2016;14(9):801-8. https://doi.org/10.1080/14787210.2016.1216313.

15. Jorgensen JH, Pfaller MA. Manual of Clinical Microbiology (M). ASM Press. 2015;1:950-2.

16. Peel TN, Sedarski JA, Dylla BL, Shannon SK, Amirahmadi F, Hughes JG, et al. Laboratory workflow analysis of culture of Periprosthetic tissues in blood culture bottles. J Clin Microbiol. 2017;55(9):2817-26. https://doi.org/10.1128/ JCM.00652-17.

17. Surawicz CM, Brandt L, Binion DG, Ananthakrishnan AN, Curry SR, Gilligan $\mathrm{PH}$, et al. Guidelines for diagnosis, treatment, and prevention of Clostridium difficile infections. Am J Gastroenterol. 2013;108(4):478-98; quiz 499. https:// doi.org/10.1038/ajg.2013.4.

18. McDonald LC, Gerding DN, Johnson S, Bakken JS, Carroll KC, Coffin SE, et al. Clinical practice guidelines for Clostridium difficile infection in adults and children: 2017 update by the Infectious Diseases Society of America (IDSA) and Society for Healthcare Epidemiology of America (SHEA). Clin Infect Dis. 2018;66(7):e1-e48. https://doi.org/10.1093/cid/cix1085.

\section{Publisher's Note}

Springer Nature remains neutral with regard to jurisdictional claims in published maps and institutional affiliations.

Ready to submit your research? Choose BMC and benefit from:

- fast, convenient online submission

- thorough peer review by experienced researchers in your field

- rapid publication on acceptance

- support for research data, including large and complex data types

- gold Open Access which fosters wider collaboration and increased citations

- maximum visibility for your research: over $100 \mathrm{M}$ website views per year

At BMC, research is always in progress.

Learn more biomedcentral.com/submissions 